\title{
Comparative Analysis of the Effectiveness of Polish and Ukrainian Basic Training Programs in Physical Education for 9-10-year-old Pupils
}

\author{
Oleksandr Mozolev ${ }^{1}$, Maryna Khmara ${ }^{1}$, Inna Shorobura ${ }^{2}$, Ihor Bloshchynskyi ${ }^{3, *}$, \\ Kostiantyn Prontenko ${ }^{4}$, Oleksandr Polishchuk ${ }^{5}$, Larysa Zdanevych ${ }^{6}$, Kateryna Kruty ${ }^{7}$

\begin{abstract}
${ }^{1}$ Department of Theory and Methodology of Physical Culture and Valeology, Khmelnytskyi Humanitarian-Pedagogical Academy, Ukraine

${ }^{2}$ Department of Pedagogy, Khmelnytskyi Humanitarian-Pedagogical Academy, Ukraine

${ }^{4}$ Department of Physical Education, Special Physical Training and Sport, S. P. Koroliov Zhytomyr Military Institute, Ukraine

${ }^{5}$ Department of Social Disciplines, Khmelnytskyi Humanitarian-Pedagogical Academy, Ukraine

${ }^{6}$ Department of Pre-School Pedagogy, Psychology and Professional Methods, Khmelnytskyi Humanitarian-Pedagogical Academy, Ukraine

${ }^{7}$ Department of Pre-School and Primary Education, Vinnytsia Mykhailo Kotsiubynskyi State Pedagogical University, Ukraine
\end{abstract} \\ ${ }^{3}$ Department of English Translation, Bohdan Khmelnytskyi National Academy of the State Border Guard Service of Ukraine, Ukraine
}

Received September 8, 2019; Revised September 16, 2019; Accepted October 7, 2019

Copyright $\bigcirc 2019$ by authors, all rights reserved. Authors agree that this article remains permanently open access under the terms of the Creative Commons Attribution License 4.0 International License

\begin{abstract}
The article examines the influence of physical education classes conducted on the basis of Polish and Ukrainian basic training programs on the level of physical fitness and physical development of pupils in secondary schools aged 9-10 years. The main features of the Polish and Ukrainian basic training programs are revealed, a comparative analysis of the advantages and disadvantages of each program has been performed. The study involved 132 pupils of 4 forms of three schools in Khmelnytskyi (Ukraine), who were divided into control (CG) and experimental (EG) groups. CG pupils $(n=67)$ were engaged in sports activities in accordance with the requirements of the Ukrainian basic training program in physical education, pupils of EG $(n=65)$ - in accordance with the requirements of the Polish basic training program. The level of physical fitness of pupils was determined by the exercises that characterize different physical qualities and physical development - by the indices: power, speed, speed-power, endurance, agility. According to the results of the conducted researches it is established that indicators of physical development of EG and CG pupils have a steady tendency for improvement during the study period, which testifies to the effectiveness of both Polish and Ukrainian basic training programs in physical education.
\end{abstract}

Keywords Physical Education, Basic Training Programs, Physical Development, Pupils

\section{Introduction}

At the present stage of development of Ukrainian society, integration processes are underway, and educational reforms are being implemented in the system of domestic school education. Considering reform changes that are taking place in education, a particularly acute problem is the deterioration of health, physical development, physical fitness and a decrease in the physical activity of pupils of secondary schools [1-5]. Such scholars as Y. Galan, K. Andrii, M. Yuriy, Y. Paliichuk, O. Moroz, O. Tsybanyuk, O. Yarmak studied the characteristics of physical conditions of 7-9-year-old schoolchildren within the process of physical education [1]. The influence of physical exercises on factorial structure of primary school age children's functional state was revealed by $\mathrm{E}$. Davydenko and V. Bileckaia [2].

Factor analysis of education development indicators in the sphere of physical culture and sports in Ukraine for the period of 1992-2016 and general tendencies of its development were researched by O. Mozolev, O. Halus, I. Bloshchynskyi and R. Kovalchuk [3]. Assessment of pupils' mobility with the help of comprehensive testing in general education schools and prognostic assessment of physical fitness of schoolchildren with health disorders using functional indicators were revealed in the works of I. Peleshenko, O. Svietlova, S. Kovalenko and A. Rybalko [4-5]. A. Bliznevsky, M. Kudryavtsev, V. Kuzmin, I. 
Tolstopyatov, O. Ionova and T. Yermakova studied the influence of personal characteristics of pupils and students on the effectiveness of the relationship to the specific physical activities [6]. That is why the priority of our research is to analyze the content of basic programs of the subject "Physical Education".

Physical education of elementary school pupils is a subject of particular attention for educators and scholars. This is due to the fact that it is at a young school age the basic physical qualities of a person are formed, children have a rather high need for movements, on the basis of which it is possible to activate pupils for further intellectual and physical development [7-10]. Taking into account the psychological characteristics of younger pupils, the basic physical education curriculum allows to plan comprehensive classes that will give the possibility to include a variety of physical exercises in the lesson, which will increase the interest and emotional state of pupils [11-14].

It is worth noting that important changes in school education are happening not only in our country but also in other European countries [15-16]. One of them is the Republic of Poland. The problem of modernization of the basic physical education training program in Poland was investigated by J. Bergier, E. Niznikowska, B. Bergier, P. Acs, F. Salonna, J. Junger [15]; D. Ponczek, I. Olszowy [16]; Z. Cendrowski [17]; J. Drabik [18]; J. Bielski [19]; G. Bober [20]; Z. Dziubinski [22]; M. Krawczak [23]; T. Wolanska [24]. There are significant differences between the Ukrainian and Polish educational systems, in particular in physical education, but there are many common problems, often related to the European integration processes, which necessitates a comparative analysis of the basic training programs of Ukraine and Poland [17-20]. A comparative analysis of basic physical education training programs was carried out by O. Mozolev [21]; P. Mazur, G. Mykhailyshyn, O. Budnyk, L. Serman [26]. Determining the level of educational achievement of students is covered in the works of A. Bliznevsky, M. Kudryavtsev, V. Kuzmin, I. Tolstopyatov, O. Ionova, T. Yermakova [6]; M. Imamoglu, O. Sener [7]; I. Tiukh [8]; T. Krutsevich, N. Panhelova, S. Trachuk [12]; T. Krutsevich, V. Vorobyov, G. Bezverkhnya [25]. The analysis of the peculiarities of physical education process organization, namely the content of the training programs for young pupils in Ukraine and Poland, will allow us to determine the level of their effectiveness and creatively adjust the ways of modernization of school physical education [21-24].

\subsection{The Aim}

The aim of the work is to perform a comparative analysis of the effectiveness of Polish and Ukrainian basic training programs in physical education and their impact on the physical fitness and physical development of 9-10-year-old pupils.

\subsection{Tasks}

1. To analyze the content of Polish and Ukrainian basic training programs in physical education for 9-10-year-old pupils, to establish common approaches and differences;

2. To check the level of development of physical abilities of pupils using the system of tests;

3. To analyze the effectiveness of Polish and Ukrainian basic physical education training programs for elementary school pupils on the level of motor skills development.

\section{Materials and Methods}

\subsection{Participants}

132 pupils of 9-10-year-old of three schools in Khmelnytskyi (Ukraine), which were divided into two groups, took part in the investigation. The control group (67 pupils) was engaged in sports activities according to the requirements of the Ukrainian basic training program in physical education, the experimental group (65 pupils) followed the requirements of the Polish basic training program.

\subsection{Research Procedure}

The research work was conducted on the basis of three comprehensive schools in the city of Khmelnitsky between September 2018 and June 2019. The pedagogical study was conducted in accordance with the requirements of the Ukrainian and Polish basic physical education training programs for elementary pupils.

The study included the following steps:

1. Theoretical analysis of the Ukrainian and Polish basic training programs in physical education for the pupils of the $4^{\text {th }}$ forms (September 2018). The task of this stage is to establish common approaches and differences in the system of physical education of young people.

2. Setting up the output data and dividing pupils into groups (October 2018). The task of this stage is to determine the level of development of pupils' physical abilities using a test system. Division of pupils into groups was made according to the requirements of representativeness.

3. Current pedagogical control (December 2018, March 2019). The task of this stage is to establish the dynamics of development of pupils' physical abilities, to adjust the training programs.

4. Final pedagogical control (May 2019). The task of this stage is to determine the level of development of pupils' physical abilities using the test system.

5. Theoretical analysis of the conducted research (June 2019). The task of this stage is to carry out a 
comparative analysis of the impact of Ukrainian and Polish basic training programs in physical education on the level of physical development of pupils. To establish general tendencies of physical development of pupils of 9-10-year-old according to the content of basic training programs in physical education and to determine the level of development of motor abilities of pupils.

To obtain the necessary information we used general scientific methods: the analysis of training programs, scientific and methodical sources, pedagogical experiment, pedagogical observation, methods of mathematical statistics.

The analysis of physical education training programs for 9-10 year olds pupils in Ukrainian and Polish schools gave an opportunity to find out the differences, common approaches and features regarding the organization and conduct of physical education classes in primary school; to get acquainted with the educational requirements for determining the level of physical fitness and physical development of pupils of this age. Analysis of scientific and methodological sources was used to study the modern views of scientists on the problems of organizing and conducting physical education classes for pupils using health-saving technologies. Pedagogical observation was used in the process of conducting classes, obtaining information about the development of motor abilities, developing the content of conducting classes in physical education, which takes into account information about the functional and physical condition of the subjects. The methods of mathematical statistics were used to reliably determine the level of development of students' motor abilities.

To determine the level of physical fitness of elementary school pupils, a test method was started that began a month after the beginning of the school year, which is related to the process of adaptation of pupils to schooling. The following stages of control were conducted at the end of the third, sixth and eighth months of classes, and included a system of tests that allowed to determine and evaluate the level of development of physical abilities for 9-10-year-old pupils at each stage of the study. The test system included the definition of the following indicators:

- $\quad$ power index (PI);

- $\quad$ speed index (SI)

- $\quad$ speed-power index (SPI);

- $\quad$ endurance index (EI);

- $\quad$ agility index (AI)

Indexes were determined according to the method of $\mathrm{T}$. Krutsevich [12, 25]:

$$
\mathrm{PI}=(\mathrm{WD} / \mathrm{BW}) \cdot 100,
$$

where

WD - pupil's wrist dynamometry (kg),

BW - pupil's body weight $(\mathrm{kg})$

$$
\mathrm{SI}=\left(\mathrm{T}_{30} / \mathrm{BL}\right) \text {, }
$$

where

$\mathrm{T}_{30}$ - time of $30 \mathrm{~m}$ distance overcoming (sec),

$\mathrm{BL}$ - pupil's body length (m)

$$
\mathrm{SPI}=(\mathrm{LJ} / \mathrm{BL}) \text {, }
$$

where

$\mathrm{LJ}$ - long jump from place $(\mathrm{cm})$,

$\mathrm{BL}$ - pupil's body length $(\mathrm{cm})$

$$
\mathrm{EI}=\left(\mathrm{D} / \mathrm{T}_{1000} \cdot \mathrm{BL}\right),
$$

where

$\mathrm{D}-1000 \mathrm{~m}$ distance (m),

$\mathrm{T}_{1000}$ - time of $1000 \mathrm{~m}$ distance overcoming (sec),

BL - pupil's body length (m)

AI was determined by measuring the time of $4 \times 9 \mathrm{~m}$ distance overcoming (sec).

\begin{tabular}{|c|c|c|c|c|c|c|c|c|c|c|c|c|}
\hline \multirow{2}{*}{ Indexes } & \multicolumn{12}{|c|}{ Points } \\
\hline & 1 & 2 & 3 & 4 & 5 & 6 & 7 & 8 & 9 & 10 & 11 & 12 \\
\hline \multicolumn{13}{|c|}{ Boys } \\
\hline PI & 46 & 48 & 50 & 52 & 54 & 56 & 58 & 60 & 62 & 64 & 66 & 68 \\
\hline SI & 3.1 & 3.2 & 3.3 & 3.5 & 3.6 & 3.7 & 3.8 & 3.9 & 4.0 & 4.1 & 4.2 & 4.3 \\
\hline SPI & 0.81 & 0.85 & 0.90 & 0.92 & 0.96 & 1.00 & 1.02 & 1.03 & 1.05 & 1.07 & 1.09 & 1.11 \\
\hline EI & 1.90 & 2.00 & 2.05 & 2.10 & 2.15 & 2.20 & 2.25 & 2.30 & 2.35 & 2.40 & 2.45 & 2.50 \\
\hline AI & 14.5 & 14.0 & 13.5 & 13.0 & 12.7 & 12.5 & 12.3 & 12.0 & 11.7 & 11.4 & 11.2 & 11.0 \\
\hline \multicolumn{13}{|c|}{ Girls } \\
\hline PI & 36 & 38 & 40 & 42 & 44 & 46 & 48 & 50 & 52 & 54 & 56 & 58 \\
\hline SI & 2.9 & 3.0 & 3.1 & 3.2 & 3.3 & 3.4 & 3.5 & 3.6 & 3.7 & 3.8 & 3.9 & 4.0 \\
\hline SPI & 0.73 & 0.77 & 0.81 & 0.84 & 0.87 & 0.90 & 0.93 & 0.96 & 0.98 & 1.00 & 1.02 & 1.04 \\
\hline EI & 1.70 & 1.80 & 1.85 & 1.90 & 1.95 & 2.00 & 2.05 & 2.10 & 2.15 & 2.20 & 2.25 & 2.30 \\
\hline AI & 15.0 & 14.5 & 14.0 & 13.5 & 13.3 & 13.0 & 12.8 & 12.6 & 12.3 & 12.0 & 11.7 & 11.5 \\
\hline
\end{tabular}

The indexes were estimated using a 12-point system according to the Table 1.

Table 1. System of the assessment of physical development of 9-10-year-old pupils, in points 


\section{Results}

Conducting a theoretical analysis of Ukrainian and Polish basic training programs in physical education for pupils of $4^{\text {th }}$ form allowed to establish common approaches to the organization of pupils' education and to determine the main differences regarding the requirements of basic programs, which are presented in Table 2.

Conducting physical education classes in accordance with the requirements of the Ukrainian and Polish basic training programs showed the following results in the development of motor abilities of pupils of 9-10-year-old (Table 3).

Table 2. Main features of basic training programs for physical education of 9-10-year-old pupils in Ukrainian and Polish schools

\begin{tabular}{|c|c|}
\hline Ukrainian schools & Polish schools \\
\hline \multicolumn{2}{|c|}{ Aim } \\
\hline $\begin{array}{l}\text { Pupils gain experience of activities: educational, cognitive, } \\
\text { practical, social; formation of pupils with stable motivation and } \\
\text { the need to preserve and strengthen their health, physical } \\
\text { development and physical fitness, comprehensive development of } \\
\text { natural abilities and moral qualities. }\end{array}$ & $\begin{array}{l}\text { Aware of the participation of pupils in physical education, sports } \\
\text { and recreation classes, while respecting safety measures, with an } \\
\text { understanding of their importance for their own health; studying } \\
\text { one's own level of physical development and functionality, } \\
\text { nurturing behaviors aimed at promoting health. }\end{array}$ \\
\hline \multicolumn{2}{|c|}{ Groups distribution } \\
\hline $\begin{array}{l}\text { Pupils are divided into main, preparatory and special medical } \\
\text { groups. They all attend compulsory physical education lessons. }\end{array}$ & $\begin{array}{l}\text { Classes in physical education groups are conducted by interests } \\
\text { (sports, recreational, tourist, dance). }\end{array}$ \\
\hline \multicolumn{2}{|c|}{ Classes organization } \\
\hline $\begin{array}{l}\text { Physical education classes are held } 3 \text { hours a week, and content of } \\
\text { the basic program is allowed to change up to } 20-30 \% \text { of the total } \\
\text { number of hours. }\end{array}$ & $\begin{array}{l}\text { Physical education classes are conducted according to the } 3+2 \\
\text { scheme (where } 3 \text { hours are scheduled classes, } 2 \text { hours of classes in } \\
\text { addition to the training program). }\end{array}$ \\
\hline \multicolumn{2}{|c|}{ Requirements affecting the assessment } \\
\hline $\begin{array}{l}\text { Attitude to lessons; skills and competences identified in the } \\
\text { training program; development of physical qualities; the pupil's } \\
\text { personal progress in physical fitness; social behavior, attending a } \\
\text { sports section, competing, following safe behaviors, and } \\
\text { maintaining health in lessons and after-hours. }\end{array}$ & $\begin{array}{l}\text { Development of physical qualities, activity of the pupils in a lesson, } \\
\text { observance of norms of behavior in accordance with the rules of } \\
\text { "Fairplay", results of participation in extracurricular activities of } \\
\text { sports and sports orientation. }\end{array}$ \\
\hline
\end{tabular}

Table 3. Indicators of development of motor abilities of 9-10-year-old pupils in control and experimental groups ( $\mathrm{n}=132, \mathrm{X} \pm \mathrm{m})$.

\begin{tabular}{|c|c|c|c|c|c|c|c|c|}
\hline \multirow{4}{*}{ Indexes } & \multicolumn{4}{|c|}{ Control group $(n=67)$} & \multicolumn{4}{|c|}{ Experimental group $(\mathrm{n}=65)$} \\
\hline & A & B & $\mathrm{C}$ & $\mathrm{D}$ & A & B & $\mathrm{C}$ & $\mathrm{D}$ \\
\hline & $\mathrm{X} \pm \mathrm{m}$ & $\mathrm{X} \pm \mathrm{m}$ & $\mathrm{X} \pm \mathrm{m}$ & $\mathrm{X} \pm \mathrm{m}$ & $\mathrm{X} \pm \mathrm{m}$ & $\mathrm{X} \pm \mathrm{m}$ & $\mathrm{X} \pm \mathrm{m}$ & $\mathrm{X} \pm \mathrm{m}$ \\
\hline & \multicolumn{4}{|c|}{ Boys $(n=34)$} & \multicolumn{4}{|c|}{ Boys $(n=32)$} \\
\hline PI & $7.3 \pm 0.38$ & $7.3 \pm 0.37$ & $7.2 \pm 0.35$ & $7.4 \pm 0.34$ & $7.2 \pm 0.35$ & $7.2 \pm 0.37$ & $7.3 \pm 0.34$ & $7.3 \pm 0.33$ \\
\hline SI & $7.8 \pm 0.41$ & $7.9 \pm 0.42$ & $8.1 \pm 0.40$ & $8.2 \pm 0.38$ & $7.9 \pm 0.39$ & $7.9 \pm 0.40$ & $8.0 \pm 0.39$ & $8.1 \pm 0.41$ \\
\hline SPI & $8.1 \pm 0.46$ & $8.1 \pm 0.45$ & $8.2 \pm 0.47$ & $8.2 \pm 0.44$ & $8.0 \pm 0.43$ & $8.0 \pm 0.42$ & $8.2 \pm 0.41$ & $8.2 \pm 0.42$ \\
\hline EI & $7.2 \pm 0.39$ & - & - & $7.3 \pm 0.36$ & $7.1 \pm 0.37$ & - & - & $7.4 \pm 0.34$ \\
\hline \multirow[t]{2}{*}{ AI } & $7.1 \pm 0.40$ & $7.6 \pm 0.41$ & $8.0 \pm 0.37$ & $8.3 \pm 0.38$ & $7.1 \pm 0.42$ & $7.8 \pm 0.44$ & $8.3 \pm 0.43$ & $8.6 \pm 0.40$ \\
\hline & \multicolumn{4}{|c|}{ Girls $(n=33)$} & \multicolumn{4}{|c|}{ Girls $(n=33)$} \\
\hline PI & $7.7 \pm 0.44$ & $7.7 \pm 0.43$ & $7.8 \pm 0.42$ & $7.8 \pm 0.43$ & $7.8 \pm 0.41$ & $7.7 \pm 0.40$ & $7.9 \pm 0.38$ & $7.9 \pm 0.37$ \\
\hline SI & $7.4 \pm 0.42$ & $7.6 \pm 0.45$ & $7.9 \pm 0.45$ & $8.3 \pm 0.44$ & $7.3 \pm 0.43$ & $7.5 \pm 0.45$ & $7.6 \pm 0.44$ & $8.0 \pm 0.46$ \\
\hline SPI & $7.6 \pm 0.45$ & $7.9 \pm 0.46$ & $8.0 \pm 0.43$ & $8.2 \pm 0.41$ & $7.5 \pm 0.42$ & $7.8 \pm 0.43$ & $8.0 \pm 0.45$ & $8.4 \pm 0.43$ \\
\hline EI & $7.5 \pm 0.42$ & - & - & $8.3 \pm 0.39$ & $7.4 \pm 0.38$ & - & - & $8.1 \pm 0.35$ \\
\hline AI & $7.6 \pm 0.37$ & $8.0 \pm 0.36$ & $8.2 \pm 0.38$ & $8.4 \pm 0.35$ & $7.8 \pm 0.39$ & $8.4 \pm 0.38$ & $8.5 \pm 0.38$ & $8.8 \pm 0.36$ \\
\hline
\end{tabular}

Legend: A - indicators at the beginning of the experiment; B - indicators at the end of the third month of classes; C - indicators at the end of the sixth month of classes; D - indicators at the end of the experiment. 
During the experiment, the endurance index was determined at the initial and final stages of the study, because in the second and third stages of the experiment, adverse weather conditions did not allow pupils to comply with the control standard.

According to the results of the study in the control and experimental groups of girls, changes in the development of speed and endurance, speed-power and agility are observed. The boys have made significant changes only in the development of speed and agility. It should be noted that in the absolute indices of the control and experimental group pupils there were changes in the development of power, speed and endurance, while at the same time there were changes in anthropometric indicators (body weight, body length), which affected the indicators of the indices being studied.

\section{Discussion}

The need to promote the values of systematic physical education and healthy lifestyles among young people is recognized by both Polish and Ukrainian scholars [2, 6, 10, 17-19, 26, 27]. The analysis of the opinions of Polish and Ukrainian primary school pupils about the need for regular physical education showed the proper level of knowledge of pupils concerning the need to maintain health at all stages of human life. Most often, a healthy lifestyle in pupils is associated with playing sports, lack of bad habits and eating well [4, 11, 16, 20-23, 26].

Physical education at school contributes to the formation of educational, cognitive, practical and social experiences in the youth $[3,5,8,28-30]$. The general development orientation of physical education in primary school improves pupils' physical and functional capacities [1, 2, 6, 17, 31]. Assessment of pupils' achievements motivates them to systematic physical education and sports, increases the interest in attending additional health-oriented classes [4, 5, 8, 16, 32-34].

The basic elementary school physical education program is aimed at forming a comprehensively developed personality with the developed motor skills and abilities, advanced motor abilities and functionalities that underlie the further full life and existence of a person [22, 29]. The basic program defines the content of the learning process, the sequence of the acquisition of theoretical knowledge, the formation of motor skills in accordance with the goals and stages of learning, clarifies the competences of pupils and allows them to determine their readiness for the next stage of education [19, 23]. The basic curriculum is only a "civilizational and cultural minimum", which is a core component of every author's physical education and mastery program, which is a prerequisite for the pupil learning process $[18,21]$. The competencies of pupils enrolled in the core curriculum are only the starting point for developing authoring programs of study and determining pupils' achievement at the end of each stage of education [24, 26].

Polish teachers pay particular attention to the education of pupils in physical education in accordance with the rules of "Fairplay". They see it not only as strict adherence to the rules of competition, but above all as the formation of a general culture of pupil youth by means of physical education, which implies respect for others, the opponent and fans [35].

According to the results of our research, the purpose, content, and directions of educational activity in the subject "Physical Education" were revealed; data on theoretical content of basic physical education training programs for 9-10-year-old pupils were expanded; the difference in indicators of development of motor abilities of pupils at different stages of study is determined; the differences, common approaches and peculiarities in the organization of the learning process in the schools of Ukraine and Poland were revealed, which made it possible to determine the effectiveness of these programs, the general tendency of their practical application in improving the indicators of physical development of elementary school pupils and the differences in the specific priority development of one or another motor abilities in boys and girls.

\section{Conclusions}

1. According to the results of theoretical analysis of basic training programs in physical education, the main differences between the Polish basic training program and the Ukrainian one were established, namely: different purpose of training; availability of compulsory physical education requirements for pupils' after-school hours, at least 2 hours per week; formation of groups for physical education based on pupils' interests; fostering a general culture of pupil behavior in accordance with "Fairplay" rules (respect for others, opponents and fans); requirements that affect the assessment of pupils' academic achievement. desire.

2. Results of the study of the level of physical development of pupils of 9-10-year-old in the control and experimental groups showed that indicators of the development of motor abilities have a stable tendency to improve throughout the time of the study, which testifies to the effectiveness of both Polish and Ukrainian basic training programs in physical education.

3. Comparative analysis of the Polish and Ukrainian basic training programs showed that the pupils of the experimental group had better dynamics of development of agility and endurance in boys, speed-power abilities in boys and girls, development of agility in girls. Pupils in the control group showed 
better dynamics of development of speed at boys, power and endurance at girls.

\section{REFERENCES}

[1] Y. Galan, K. Andrii, M. Yuriy, Y. Paliichuk, O. Moroz, O. Tsybanyuk, O. Yarmak. Characteristics of physical conditions of 7-9-year-old schoolchildren within the process of physical education, Journal of Physical Education and Sport, Vol.18, No.5, 1999-2007, 2018. doi: 10.7752 / jpes.2018.s5297

[2] E. V. Davydenko, V. V. Bileckaia. Factorial structure of primary school age children's functional state, Pedagogics, psychology, medical-biological problems of physical training and sports, Vol.2, 34-38, 2011. [in Ukrainian].

[3] O. Mozolev, O. Halus, I. Bloshchynskyi, R. Kovalchuk. Human resources management of educational development in sphere of physical culture and sports in Ukraine: comparative analysis (1992-2016), Journal of Physical Education and Sport, Vol.19, (Supplement issue 1), 185-192, 2019. doi: 10.7752/jpes.2019.s1028

[4] I. Peleshenko. Assessment of pupils' mobility with the help of comprehensive testing in general education schools, Slobozhansky scientific sports journal, Vol.2, 35-38, 2010. [in Ukrainian].

[5] O. Svietlova, S. Kovalenko, A. Rybalko. Prognostic assessment of physical fitness of schoolchildren with health disorders using functional indicators, Journal of Physical Education and Sport, Vol.16, No.4, 1115-1121, 2016. doi: 10.7752/jpes.2016.04179

[6] A. Bliznevsky, M. Kudryavtsev, V. Kuzmin, I. Tolstopyatov, O. Ionova, T. Yermakova. Influence of personal characteristics of pupils and students on the effectiveness of the relationship to the specific physical activities, Journal of Physical Education and Sport, Vol.16, No.2, 424-432, 2016. doi:10.7752/jpes.2016.02066

[7] M. Imamoglu, O. A. Sener. Comparison of children's motor performances by age and gender, Universal Journal of Educational Research, Vol.7, No.1, 10-15, 2019. doi: 10.13189/ujer.2019.070102

[8] I. A. Tiukh. Factorial analysis of primary school age children's physical health parameters, Young sport science of Ukraine, Vol.10, 44-52, 2007. [in Ukrainian].

[9] M. Mohsin. Adaptation perspective in implementing physical education in schools, International Journal of Sports and Physical Education, Vol.4, No.2, 28-36, 2018. doi:http://dx.doi.org/10.20431/2454-6380.0402004 www.arcjournals.org

[10] K. Prontenko, I. Bloshchynskyi, G. Griban, Ye. Zhukovskyi, T. Yavorska, P. Tkachenko, D. Dzenzeliuk, N. Dovgan, S. Bezpaliy, V. Andreychuk. Formation of readiness of future physical culture teachers for professional activity, Universal Journal of Educational Research. Vol.7, No.9, 1860-1868, 2019. doi: 10.13189/ujer.2019.070903

[11] S. I. Prysiazhniuk. Features of the methodology of development of physical qualities of pupils of primary education of secondary school, Kyiv: Publishing center NUBiP of Ukraine, 2014. [in Ukrainian].

[12] T. Krutsevich, N. Panhelova, S. Trachuk. Control of physical preparedness of schoolchildren using index method, Journal of Physical Education and Sport, Vol.19, No.2, 1145-1152, 2019. doi: 10.7752/jpes.2019.02166

[13] N. Dinc, P. Guzel, S. Ozbey, T. Besikci, S. Seyhan, N. Kalkan, G. Gezer. Obesity prevalence and physical fitness in school-aged children, Universal Journal of Educational Research, Vol.7, No.3, 659-663, 2019. doi: 10.13189/ujer. 2019.070303

[14] G. Griban, K. Prontenko, Yu. Kostyuk, P. Tkachenko, T. Yavorska, Ye. Zhukovskyi, V. Shaverskiy. Formation of middle school pupil movements using basketball, Journal of Physical Education and Sport, Vol.18, No.1, 304-309, 2019. doi: 10.7752/jpes.2018.01041

[15] J. Bergier, E. Niznikowska, B. Bergier, P. Acs, F. Salonna, J. Junger. Differences in physical activity, nutritional behaviors, and body silhouette concern among boys and girls from selected European countries, Human Movement, Vol.18, No.1, 19-28, 2017. doi:10.1515/humo-2017-0009

[16] D. Ponczek, I. Olszowy. Youth lifestyle and its impact on health, Problems of Hygiene and Epidemiology, Vol.2, 260-268, 2012. [in Polish].

[17] Z. Cendrowski. Nowa podstawa programowa wychowania fizycznego i edukacji zdrowotnej nao golniejszymtle problemo w cywilizacyjny chizdrowotnych, Kultura fizyczna,Vol.5-6, 1-13, 2009. [in Polish].

[18] J. Drabik. Nowy paradygma tkultury fizycznej, Kultura fizyczna, Vol.9-10, 62-64,m2010. [in Polish].

[19] J. Bielski. Wychowanie fizycznewre formowanej edukacji. Budowa programy w Autorskich. Standardy osiągnięć. Ocena ucznia, Lider: Wydanie specjalne, 8-12. 1999. [in Polish].

[20] G. Bober. Kryteria oceny ucznia z wychowania fizycznego, Wychowanie Fizycznei Zdrowotne, No.1, 12-14, 2003. [in Polish].

[21] O. Mozolev. Comparative analysis of mechanisms of education development management in the sphere of physical culture and sports in Ukraine and Poland. News of Science and Education, Vol.2, No.50, 45-50, 2017.

[22] Z. Dziubinski. Nowa podstawa programowa - wychowania fizycznego i zdrowotnego, Wychowanie fizyczne i zdrowotne, Vol.7, 31-33, 2010. [in Polish].

[23] M. Krawczak. Autorski program wychowania fizycznego "Aktywność fizyczna sposobem na zdrowie", Wychowanie Fizyczne I Zdrowotne, Vol.10, 36-39, 2009. [in Polish].

[24] T. Wolanska. Wychowanie fizyczne w minimachp rogramowych,Wychowanie Fizyczne, Vol.4, 255-261, 2001. [in Polish].

[25] T. Krutsevich, V. Vorobyov, G. Bezverkhnya. Control in the physical education of children, adolescents and young people. Kyiv: Olympic literature, 2011. [in Ukrainian].

[26] P. Mazur, G. Mykhailyshyn, O. Budnyk, L. Serman. Promoting a healthy lifestyle among schoolchildren (comparative study between Poland and Ukraine), Journal 
of Physical Education and Sport, Vol.18, No.2, 1161-1167, 2018. doi: 10.7752/jpes.2018.2173

[27] I. Bodnar, A. Andres. Tests and standards for express control of physical fitness and health of students of middle school age, Pedagogy, psychology and biomedical problems of physical education and sport, Vol.4, 11-17, 2016. [in Ukrainian].

[28] F. Trudeau, R. J. Shephard. Physical education, school physical activity, school sports and academic performance, International Journal of Behavioral Nutrition and Physical Activity, Vol.5, No.3, 74-83, 2008.

[29] T. Balga , B. Antala , J. Argajová. Attitudes of elementary school pupils towards physical education and their differentiation from the point of view of age, sporting level and gender, Journal of Physical Education and Sport, Vol.19, No.1, 552-559, 2019. doi: 10.7752/jpes.2019.01081

[30] P. Vişan, V. Vişan. Development of psychomotor capacity in 3rd and 4th grade primary school pupils, Journal of Physical Education and Sport, Vol.17, (Supplement issue 5), 2279-2284, 2017. doi: 10.7752/jpes.2017.s5244

[31] K. Sivrikaya, M. A. Ziyagil, M. Çebi. Relationship between body mass index and skin fold thickness in exercised and sedentary boys and girls, Universal Journal of Educational Research, Vol.7, No.1, 48-54, 2019. doi: 10.13189/ujer.20 19.070107

[32] H Acar, N. Eler. The effect of balance exercises on speed and agility in physical education lessons, Universal Journal of Educational Research, Vol.7, No.1, 74-79, 2019. doi: 10.13189/ujer.2019.070110

[33] H. Çolak. The impact of daily habits on the physical activity levels of children aged 7-10: an investigation, Universal Journal of Educational Research, Vol.7, No.1, 118-125, 2019. doi: 10.13189/ujer.2019.070116

[34] O. Mozolev, I. Bloshchynskyi, O. Alieksieiev, L. Romanyshyna, L. Zdanevych, I. Melnychuk, K. Prontenko, V. Prontenko. Influence of modern fitness technologies on the state of health and development of motor abilities of 17-19-year-old female students, Journal of Physical Education and Sport, Vol.19, (Supplement issue 3), 917-924, 2019. doi: 10.7752/jpes.2019.s3132

[35] M. Czechowski, A. Dabrowska. Fairplay w sporte i zyciumlodziezy, Zeszyt, Vol.1. Warszawa: ESCRELLA, 2011. [in Polish]. 